\title{
(Re)orienting food activism toward social justice
}

\author{
Review by Andrea Woodward, Berea College*
}

Review of Food Justice Now!: Deepening the Roots of Social Struggle by Joshua Sbicca. (2018). Published by University of Minnesota Press. Available in hardcover, paperback, and Kindle; 288 pages. Publisher's website: https://www.upress.umn.edu/bookdivision/books/food-justice-now

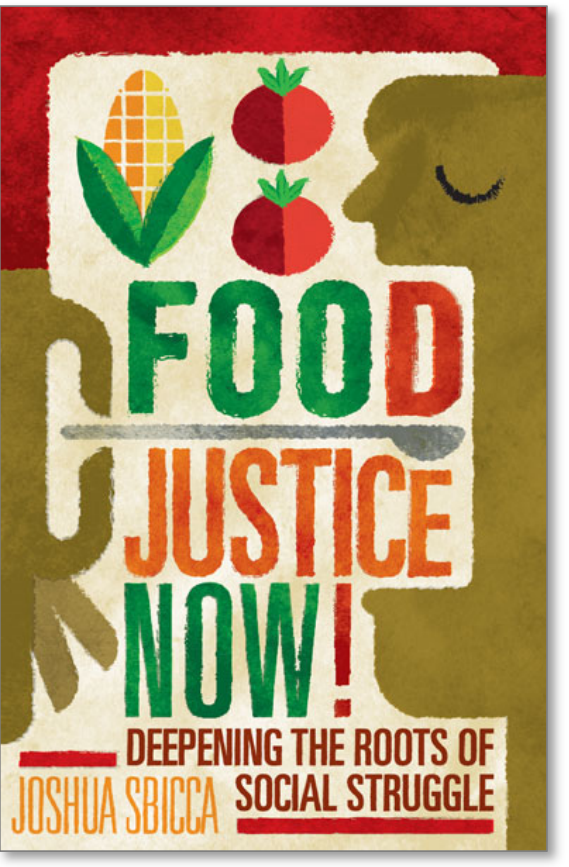

Submitted December 10, 2018 / Published online July 24, 2019

Citation: Woodward, A. (2019). (Re)orienting food activism toward social justice [Book review]. Journal of Agriculture, Food Systems, and Community Development, 9(1), 141-143. https://doi.org/10.5304/jafscd.2019.091.004

Copyright (C) 2019 by the Author. Published by the Lyson Center for Civic Agriculture and Food Systems. Open access under CC-BY license.

\begin{abstract}
A fitting place to begin a discussion about - Joshua Sbicca's new book, Food Justice Now!, is with a story he shares near the middle of the book, where readers are introduced to a progressive farm situated along the U.S.-Mexico border. Wild Willow offers education for new organic farmers, provides healthy food to local consumers, hosts community gatherings, and practices non-wage exchange for labor-approaches considerably more sustainable and community-oriented than those typically used in our current food system. The farm stops short, however, of inserting itself into any kind of movement to support the rights of those migrant workers who perilously navigate the border on which the farm sits or to advocate for

* Andrea Woodward is associate professor of social sciences at Berea College, where her teaching and research focus on social inequality and the food system. She can be reached at Berea College, 101 Chestnut Street, CPO 2156, Berea, KY 40404 USA; andrea woodward@berea.edu.
\end{abstract}

humane immigration reform. In so doing (and in not so doing), Wild Willow provides alternatives for local growers and consumers, but it does not confront the systems that dictate and limit the range of what those alternatives can look like. As such, the farm and the border it is situated upon are a powerful metaphor for this book's message. While most food-based activism does not take place in the literal face of racialized, economic, and political borders, it always does so in a figurative sense. Food activism ignores this to the detriment of social justice. So, what does it take to cross these boundaries, and why aren't more food activists doing so? What does it look like when they do, and what has this looked like historically? A central purpose of this book is to answer these questions. In the process, it offers a constructive and hopeful challenge to movements narrowly focused on issues such as health or the environment to aim higher at social justice. 
Sbicca spent five years researching food justice activists in California and found himself connecting the dots from food and social justice to mass incarceration, labor exploitation, and immigration. While these do not often appear together in discussions about food politics, in this context the combination makes perfect sense; after all, they are the social sites where, like tectonic plates on which everything around us is built, white supremacy and neoliberal capitalism fuse together to create some of the worst human-made disasters of our time. Among the rubble, food provides a powerful foothold from which to rebuild and reconfigure a socially just future. Sbicca's book walks readers through how this is happening in three different contexts in California, after first providing a historical context that reminds readers that the food movement does not need to be completely reimagined to attain social justice goals - it has a strong history that has not been given its due but that nevertheless offers many examples, lessons, and cues for activists today.

A central claim of the book is that the future of food-centered movements will depend on their ability to create more than alternatives (organic, local, etc.) within our neoliberal capitalist and white supremacist system. To guide this future, Sbicca first looks at how movements of the past have gone beyond alternatives to confront racial and economic inequalities head on. The first chapter walks readers through the agrarian populist movements of the post-Civil War era, the origins of the organic movement, the decades of farm worker organizing that made successes of the United Farm Workers possible, and the Black Power movement. After establishing the considerable legacy and lessons these movements have left behind for contemporary food justice movements, the second chapter presents a case study of a nonprofit, Planting Justice, that uses permaculture gardens to confront racism and other structural inequalities that have produced mass incarceration, high recidivism rates, and related resulting social problems in the United States. The organization creates meaningful, living-wage work that engages people in their communities, provides workers with mentoring and access to resources necessary for working through trauma, and lobbies local governments to prioritize investments in community-based re-entry programs over building more jails. Sbicca introduces a central idea of how "instead of seeing food as an end, food becomes a means for social change" (p. 79).

From mass incarceration, the book moves onto labor organization using the example of United Food and Commercial Workers (UFCW) Local 77, which actively confronts how structural racism and neoliberal capitalism have pitted oppressed groups against one another. First, the union resists narratives that place the white working class in opposition to immigrants and people of color. It has done this by shifting the composition of its leadership and the issues it tackles to represent the ethnoracial diversity and realities of the local workforce. Second, the union refuses to perpetuate divisions among economically oppressed groups that have been set in place by the neoliberal lie that affordable prices for consumers are incompatible with living wages for workers. Through leadership that reflects the ethnic and racial diversity of the workforce and through lobbying for higher wages and humane immigration reform, UFCW Local 77's confrontational politics is rooted in a kind of solidarity that enables it to fight for expanded opportunity for all, rather than small slices of turf for only some.

The last of the three case studies brings us back to the immigration scenario at the beginning of this review, where the U.S./Mexico border serves as a metaphoric line between food activism and food justice. The boundary between staff at San Diego Roots, which operates Wild Willow Farm, and farmworkers is not only geographic but also racial and ideological. Here, nonprofit staff committed to a more just food system have nevertheless normalized, rationalized, and even essentialized the social order found at the border and its militarization. This is in no small part due to the blind spots that arise from having a nearly all-white staff and leadership whose easy relationship with the border puts them out of touch with the deeper exigencies of social justice. The work of UFCW Local 77 described previously is brought back into focus here and in further detail to demonstrate what confronting an unjust system looks like in comparison to an approach 
that seeks instead to only provide alternatives within it.

The chapters focusing on these three case studies build theory that connects to practice and can inform current food-based social justice work, and in so doing the author places this book in the domain of public sociology. The tone in these chapters is most accessible, however, to a public that is conversant in Gramsci's conjunctural analysis, Boggs's prefigurative politics and dialectical humanism, and Marx's dialectical materialism. As a result, while much of the book speaks to more of an academic than public audience, excerpts from the book have appeared in The Utne Reader, and Sbicca contributed a chapter based on his research to The New Food Activism (Alkon \& Guthman, 2017), a text more specifically directed at audiences seeking a more accessible discussion and examples of how food activism and social justice activism can be one and the same. Overall, Food Justice Now! seems particularly geared to activists and academics seeking social theory to inform social justice work, particularly with a focus on how structural racism and neoliberal capitalism drive inequalities in our food system and larger society.

While the book locates the problems of our food system in institutional racism and neoliberal capitalism, these roots are also entangled with a patriarchy that is intermittently identified but never specifically analyzed in the book. More emphasis on this dimension of social inequality as it is manifested in our food system would have been useful. However, the groups represented in Sbicca's research (labor unions, formerly incarcerated men, and migrant farmworkers) leave the book's analysis best positioned to dissect how the food justice movement can confront economic and racial structural inequalities in particular, and that contribution is considerable. The final chapter gives glimpses of how land, labor, community development, health, and sustainability might look if we are serious about upending social problems such as hunger and climate change. In so doing, it delineates how the current structure of our food system precludes the kind of change necessary to achieve justice, and on the policy front, how a farm bill focused on social justice would appear radically different from the one we have now.

\section{Reference}

Alkon, A. H., \& Guthman, J. (Eds.). (2017). The New Food Activism: Opposition, Cooperation, and Collective Action. Oakland: University of California Press. 